\title{
Domestic Water Demand During Droughts in Temperate Climates: Synthesising Evidence for an Integrated Framework
}

\author{
D. Manouseli ${ }^{1}$ (D) B. Anderson ${ }^{1} \cdot$ M. Nagarajan $^{2}$
}

Received: 30 May 2017 / Accepted: 25 September 2017 /

Published online: 6 October 2017

(C) The Author(s) 2017. This article is an open access publication

\begin{abstract}
In the upcoming years, as the population is growing and ageing, as lifestyle changes create the need for more water and as fewer people live in each household, the UK water sector will have to deal with challenges in the provision of adequate water services. Unless critical action is taken, every area in the UK may face a supplydemand gap by the 2080s. Extreme weather events and variations that alter drought and flood frequency add to these pressures and there is therefore a need to develop evidence-based drought scenarios models for water management purposes. However, little evidence is available about householders' response to drought and there are few if any studies that have synthesised this evidence. In response, this paper discusses the current empirical literature on the factors driving domestic water consumption under both 'normal' and drought conditions. The paper identifies the limited availability of evidence on the many different and evolving factors affecting domestic consumption under both 'normal' and drought conditions and stresses the need for the inclusion of inter and intra household factors as well as water use practices in future demand forecasting models. The paper then presents 'Water Cultures' as an integrative modelling framework to combine the limited evidence that is available on the interactions of social norms, practices and material cultures. This enables the paper both to capture both the uncertainty and heterogeneity of individual and/or household level variation and also outline the research gaps that need to be addressed.
\end{abstract}

Keywords Climate change $\cdot$ Domestic water demand $\cdot$ Drought $\cdot$ Water use practices

D. Manouseli

d.manouseli@soton.ac.uk

1 Energy \& Climate Change Division, Faculty of Engineering and the Environment University of Southampton, Southampton, UK

2 Coventry University, Coventry, UK 


\section{Introduction}

Climate change is expected to affect regions around the world, possibly causing floods and droughts of increased frequency and magnitude as well as changes in water use behaviours (Olmstead 2013). There is a general consensus that the United Kingdom (UK) will probably experience warmer conditions and lower summer rainfall (Jenkins et al. 2010; Parker 2014). In South East England, a region already suffering water stress due to population growth and changing water use habits, summer precipitation is projected to decrease from an average of less than 25 wet days (Met Office 2017) by $9 \%$ by the 2080s (Jenkins et al. 2010). Importantly, residential customers typically use the most water of any sector (De Oreo et al. 2016) thus control of domestic demand is a priority in the UK.

Partly in response to this acute situation, the Department for Environment, Food \& Rural Affairs (DEFRA 2008) have set targets for reducing daily domestic demand from 150 to 1301 per person before 2030. To achieve these targets, an understanding of the factors affecting water consumption at the household and societal levels is required (Browne et al. 2013; Parker and Wilby 2013). This understanding can then be embedded in future demand projection models that can be used to assess the costs and benefits of potential intervention scenarios under a range of climatic and hydrological conditions (Prudhomme et al. 2015). These analyses can then inform interventions encompassing technologically driven water efficiency, demand-reduction (e.g. via metering and leakage control) and/or re-configured social practices and new water-using norms.

Whilst there has been considerable research into the factors determining everyday ('normal conditions') domestic water demand (see e.g. Gato 2006; Jorgensen et al. 2009; Arbues et al. 2010; Parker and Wilby 2013; Critchley et al. 2015) there have been limited attempts to embed these understandings and their associated uncertainty into models of future demand for longer term resource planning purposes in the UK (Herrington 1998; Williamson et al. 2002; Downing et al. 2003; Goodchild 2003). The 2003 Water Act requires UK water companies to include demand forecasting in their Water Resources Management Plans (WRMPs) and prepare drought plans. Some of these forecasts predict consumption decreases but the range of forecasts is almost $50 \%$, demonstrating both the uncertainty and the high geographic variance of water demand in the UK (Atkins 2015) as well as the difficulty and cost of gathering the range of data needed (Memon and Butler 2006). This is further complicated by the influences of local policy, cultural norms, changes in population and variations in the adoption of water efficient technologies such that the effective modelling of intervention scenarios is very difficult to achieve (Arbues et al. 2010). Furthermore, little is known about householders' response to drought and there are few if any studies which incorporate the evidence that exists into models of demand forecasting in support of operational decisions about the most likely cost-effective drought management measures.

In response, this paper lays the groundwork for modelling domestic demand response under drought conditions in temperate climates (such as the UK) by reviewing the concepts and evidence on which a comprehensive model might be based. The work focuses on the available empirical data and current literature on estimating and forecasting water consumption under both 'normal' and drought conditions. We then develop a synthesised framework which, borrowing from Stephenson et al. (2010) we term 'Water Cultures'. This framework enables the integration of the range of concepts and evidence 
reviewed which, when applied to the review of modelling methods, then identifies gaps in the evidence base and suggests key directions for future work.

\section{Factors Affecting 'Everyday' Domestic Water Demand}

The price of water has been one of the most commonly analysed factors affecting water consumption (Chicoine et al. 1986; Mylopoulos et al. 2004; Gaudin 2006; Grafton et al. 2011; Mieno and Braden 2011; Ahmad et al. 2016). Overall, below a certain volume of water consumption, demand is often found to be unresponsive to price change making price manipulation an ineffective tool for demand control even were it to be socially acceptable (Espey et al. 1997; Martinez-Espiñeira 2002; Worthington and Hoffman 2008; Arbues et al. 2010).

Similarly, much research has explored the effects of household income on demand (e.g. (Hajispyrou et al. 2002; Harlan et al. 2009; Schleich and Hillenbrand 2009; Willis 2010; Mieno and Braden 2011)) and in general consumption is found to increase with affluence. In the UK it has been shown that off-peak water demand is strongly related to ACORN $^{1}$ geodemographic classification (Kowalski and Marshallsay 2005) and thus, it is claimed, income (Edwards and Martin 1995; Lawson 2015). On the other hand, Pullinger et al. (2013) find that water-use practices bear little relationship to ACORN class and such data is well-known to both suppress inter-household variation in consumption producing misleading conceptions of 'average' water consumers (Sofoulis 2011) and also to suffer from ecological fallacy effects where geo-demographic level averages are assumed to be adequate representations of individual households.

Household size is a key driver of water demand and due to economies of scale, average per capita consumption decreases as household size increases (Lyman 1992; Schleich and Hillenbrand 2009; Jorgensen et al. 2009; Bernardo et al. 2015; Manouseli et al. 2017). This can be attributed to shared water-uses (e.g. cooking and garden watering) and there may be a household size threshold beyond which these economies of scale diminish, thus causing water consumption to be less than proportional to household size (Arbués et al. 2004). It is also generally accepted that the elderly tend to consume less water in their homes than younger people (Domene and Saurí 2006; Musolesi and Nosvelli 2007; Kenney et al. 2008; Waterwise 2009; Pullinger et al. 2013; Makki et al. 2014) possibly due to young people's more water intensive habits.

Apart from household or occupant 'attributes', local temperature and drought conditions have been shown to have a positive relationship with consumption, but there is an inverse relationship between consumption and precipitation (Maidment and Miaou 1986; Lyman 1992; Martinez-Espiñeira 2002; Shirley Gato et al. 2007; House-Peters and Chang 2011; Parker and Wilby 2013) whilst evapotranspiration can also be a major positive factor (Agthe et al. 1986; Zhou et al. 2000; Goodchild 2003). Consequently, several studies have suggested that garden size and landscaping type significantly affect consumption (Guhathakurta and Gober 2007; Harlan et al. 2009; House-Peters et al. 2010). However, in the UK and in similar built environments this will be limited to the small proportion of households that not only have a garden but also use supplied water to irrigate it (Pullinger et al. 2013).

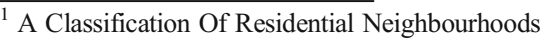


Detailed 'micro-component' consumption data have been used to examine end-use patterns (Beal and Stewart 2011; Carragher et al. 2012; Makki et al. 2014; Parker and Wilby 2013; Stewart et al. 2013; UKWIR 2013). These show that households with very similar characteristics can have very different patterns of micro-component water use (Medd and Shove 2007). Indeed, inter-household variation has received limited attention and there is a relatively poor understanding of how and why demand varies from property to property (CIWEM 2016) and over time although the concept of social practices has recently gained considerable leverage in this respect (Shove 2003; Allon and Sofoulis 2006; Shove et al. 2012; Browne et al. 2013).

Overall, it can be seen that a wide range of factors influence residential water consumption and this makes the estimation of household water demand extremely complex (Medd 2007; Browne et al. 2013; Parker and Wilby 2013). However, it is equally clear that there is strong evidence for the inclusion of a range of socio-economic factors as well as dwelling characteristics and local climatic conditions in any residential demand model.

\section{Intervention Effects}

In addition to the studies of 'everyday' water demand, there has also been analysis of the role that various interventions might play in reducing 'normal' consumption.

\subsection{Metering}

Metering schemes can decrease consumption by between 7 and 35\% (Herrington 1998; Dalhuisen et al. 2003; Domene and Saurí 2006; Worthington and Hoffman 2008; Energy Saving Trust 2013). Mainly, this is thought to be due to publicity and leakage reduction that often accompanies metering schemes (Campbell et al. 2004; Robinson et al. 2014), although as customers get used to being metered, their behaviour may change and even revert (Inman and Jeffrey 2006). A micro-component based UK study demonstrated that the median household total was $311 \mathrm{l}$ /day in unmetered homes compared to $192 \mathrm{l}$ /day in metered ones (Parker 2014) and that unmetered users are more likely to be influenced by climate related factors. Similar studies in the USA have shown that metered and unmetered homes' average consumption was $200 \mathrm{l} / \mathrm{c} / \mathrm{d}$ and $223 \mathrm{l} / \mathrm{c} / \mathrm{d}$ respectively (Linkola et al. 2013) and that metering caused a larger reduction in outdoor rather than indoor water use.

More recently, analysis of a regional UK universal metering program has suggested an average $16.5 \%$ drop in water consumption as well as a notable drop in energy consumption potentially due to the decreased use of hot water (Ornaghi and Tonin 2015). A second scheme, which uniquely combined switching from non-metered to metered, efficiency retrofitting and education also claimed to achieve water savings (Waterwise 2010). Further, analysis of the UK drought and hosepipe bans of 2012 suggested that behaviour change was more prominent among metered households (75\% took action) than unmetered ones (59\%) (UKWIR 2013).

\subsection{Water Efficient Technologies}

Water companies also promote the installation of water saving devices in households through water efficiency programmes which depend strongly on voluntary participation. 
Water saving devices include dual flush conversion devices, water butts, cistern displacement devices, water efficient showerheads and tap inserts, which are either fitted by a plumber or by the residents themselves. Retrofitting is often accompanied by a public awareness campaign to promote behaviour change. Evaluation of water efficiency initiatives is common but is time consuming, costly and often impossible to account for all factors that have a direct influence on consumption such as the weather and specific household habits. In parallel, it is challenging to distinguish the effects of individual efficiency measures that are usually applied simultaneously. Thus, only a few studies have presented results for such individual effects and we summarise these in Table 1.

The table shows that the savings reported differ both within and between countries with efficient showerheads saving from 23 to $118 \mathrm{l} / \mathrm{hh} / \mathrm{d}$, while conversion to dual flush toilet can produce savings of $11-131 \mathrm{l} / \mathrm{hh} / \mathrm{d}$ due to different settings and programme intensities but also to the different savings evaluation methods used (Manouseli et al. 2017).

Multi-intervention studies have shown that water saving devices can reduce overall consumption by $10 \%$ (Kenney et al. 2008), but others have proved less successful, with regulation forcing the installation of efficient products producing a 3.5\% reduction (Campbell et al. 2004). In the case of free water saving kits for customers, the latter study showed that consumption appeared to increase, indicating a possible rebound effect.

Two large scale American studies showed that the biggest potential for indoor water conservation resulted from the retrofit of toilets and washing machines (Mayer et al. 2004). Other studies have shown that shower display monitors proved initially successful in reducing a shower's duration by almost $30 \%$ but shower use increased back to preinstallation levels after four months (Stewart et al. 2013).

In the UK, an initial 2006-2008 trial installing several water efficient devices produced an $8 \%$ reduction but a follow-up 2007-2008 trial distributing water saving kits only produced a $1.2 \%$ reduction (Waterwise 2010). However, a control group was not used in the savings' evaluation. A similar study showed that Essex \& Suffolk Water's water saving kits (shower aerators, save-a-flush devices and others) produced a saving of 3.6 1/household/day or about $1.4 \%$ of median UK household demand (Ashton et al. 2015).

More recent work has suggested that consumption reduction varies by household attributes such as household size and socio-economic status. Thus there is evidence that financially stretched households and those with single occupants show larger percentage reductions in response to water efficiency initiatives (Turner et al. 2005; Lawson 2015; Manouseli et al. 2017). In the case of the latter, the one-to-one engagement with the installer may have encouraged behavioural change, which lost impact as the messages were diluted in larger households.

Lifestyle compromise is considered to be one of the biggest barriers to adopting water efficient technologies at home although it has been estimated that switching to a dual flush toilet could save more than 7000 1/capita/year and lead to $£ 80$ annual savings on water bills for an average household (Energy Saving Trust 2015). Similarly, analysis of end use consumption data in Queensland, Australia showed a $25 \%$ consumption reduction for homes with higher water stock efficiency, underlining the value of continued implementation of retrofit programs (Carragher et al. 2012).

There is therefore evidence that considerable water savings can be achieved by retrofitting water-efficient devices to the existing housing stock. However, it is also 
evident that results from water efficiency programs vary greatly, even in the cases where the programs took place in very similar settings. This variation in household response adds further complexity to household demand forecasting as it is likely to produce a wide range of outcomes under ostensibly similar conditions.

\subsection{Information Campaigns}

Attitudes towards water use and general environmental issues are often suggested to influence water demand (Dolnicar and Hurlimann 2010) and so soft interventions such as education and public awareness campaigns aim to alter behaviours and water use habits by spreading the message of water conservation (Hurd 2006).

Unfortunately the role of attitudes has been less frequently examined than sociodemographic factors or price (Ferrara 2008). A small scale Australian study suggested that respondents with 'very positive water conservation attitudes' consumed much less water compared to other groups (Willis et al. 2011) and others have shown that beliefs about how neighbours would act on water conservation had a positive effect on water saving intentions (Lam 2006) while better-educated consumers may be more likely to adopt water saving habits. This may have been because they tended to be wealthier and so could afford to buy more water saving devices for their homes (Kemmelmeier et al. 2002; Millock and Nauges 2010; Martinez-Espiñeira 2002). However, experimental or observational studies have shown that even when attitudes towards conservation were very positive, this did not translate to actual behaviour (Barr 2006; Jensen 2008; Dolnicar and Hurlimann 2010; Hoolohan and Browne 2016). Furthermore interviews with unmetered householders, water management teams and regulators in the UK found no evidence of a strong relationship between 'household's attitudes towards water conservation' and 'their actual consumption levels' (Medd 2007).

As might be expected therefore, measures such as awareness campaigns usually lead to small changes in water consumers' behaviours, even though people appear more informed (Bello-Dambatta et al. 2014). As a result, it is usual to run them in parallel to efficiency programs so that their effectiveness can be maximised (Turner et al. 2010). Importantly, the effect of such programs has proved to be significant mainly in times of water scarcity and crisis but it usually diminishes within a year (Wang et al. 1999; Alliance for Water Efficiency 2010).

In Zaragoza, Spain, long term awareness and sustained water efficiencies were achieved after a year of local community engagement and participation (Inman and Jeffrey 2006). This success can be attributed to the interaction between the suppliers of efficiency products and the local community and the increase in the public's awareness of the need to save water. In contrast, a similar campaign in the UK using mail and advertising did not affect water demand (Burton et al. 2007) although there is some evidence that past experience of droughts and use restrictions contribute to positive attitudes toward conservation (Bournemouth Water 2014). Furthermore awareness campaigns did not add substantial savings to water metering in the USA, with the exception of household members who were willing to compromise their enjoyment, by taking shorter showers (Linkola et al. 2013).

Evidently, there is a gap between attitudes and behaviour and this is problematic for effective information-based interventions since most water conservation campaigns typically aim to change attitudes via media messages. As the evidence shows, such campaigns may have 
little effect on their own and be potentially short-lived although may be of most use during specific drought or shortage periods.

\section{The Effectiveness of Drought Specific Measures}

During droughts, UK water companies often increase water efficiency programme efforts (Mukheibir et al. 2013) but can additionally impose emergency pricing and rationing programs and temporary restrictions on non-essential water-use. Such restrictions are generally only applicable to external water uses such as garden watering, car washing and filling of swimming pools and are associated with penalties for non-compliance.

Little is known about the effect of restrictions explicitly, largely because they are usually combined with other price or non-price efforts (Kenney et al. 2008). However qualitative evidence suggests that while mandatory bans on 'non-essential' external water use may have some effects, they also legitimise all other water use as 'normal' and 'essential' thus hampering efforts to reduce overall consumption levels (Chappells et al. 2011). There is evidence that mandatory irrigation restrictions can reduce demand by between 13, and 55\% (Renwick and Archibald 1998; Renwick and Green 2000) but voluntary restrictions have proved to be of limited value (Kenney et al. 2008). More moderate restrictions have been shown to produce approximately a $12 \%$ reduction in consumption with differential response by low and high water users (Kenney et al. 2008). One study showed that the top $20 \%$ of Seattle water users decreased their consumption by over $30 \%$ and by $15 \%$ under mandatory and voluntary restrictions respectively (Polebitski and Palmer 2010). In Greece, outdoor use restrictions during peak evapotranspiration hours reduced consumption by 25-35\% (Kanakoudis 2002) whilst in Queensland, Australia watering restrictions combined with efficient devices rebates and awareness campaigns resulted in a 50\% reduction of domestic demand between 2008 and 2009 (Beal et al. 2010). There is also evidence that the sensitivity of a household's outdoor consumption to droughts is associated with property characteristics rather than socioeconomic attributes. Thus newer houses were seen to be the most sensitive to drought and produced the largest response (House-Peters et al. 2010).

During the 2006 UK droughts, indoor water use routines remained unchanged but many minor changes in outdoor use habits were recorded (Medd 2007). These changes were not caused by temporary restrictions alone, but were also motivated by social interactions and convenience. During the drought of 2012, hosepipe bans were imposed by seven UK water providers and survey data collected after the 2012 restrictions suggests that outdoor use was reduced by 22\% during 2012 (UKWIR 2013). However, the restriction period coincided with heavy rainfall and decreased temperatures, which acted as potential confounders in the analysis and more detailed micro-component derived evidence suggests the demand reduction during 2011-2012 was not caused by the restrictions but by the unusually wet weather (Parker 2014).

Overall the evidence suggests that consumers may be more likely to reduce their consumption via efficient technologies and behaviour change rather than temporary external use bans although the latter may have a role to play in highlighting levels of unsustainable consumption (Dessai and Sims 2010; Parker 2014). However, as the previous section also showed, the degree of response to restrictions may be affected by previous experience of drought and may also be relatively short-lived (Wang et al. 1999). A particular challenge in modelling response to drought is therefore the development of 
indicators capable of distinguishing different program intensities and determining the longevity of demand reductions after restrictions are lifted (Mukheibir et al. 2013).

\section{5 'Water Cultures' as an Integrated Framework for Scenario Modelling}

Historically, system dynamics approaches have generally been used to model the effects of housing, population growth, pricing or climate change on water demand (House-Peters and Chang 2011; Qi and Chang 2011). However the problematic suppression of intrahousehold variation inherent in such approaches (Sofoulis 2011) has led some to recommend a transition to micro-level modelling that applies processes to a sample of individual households (Williamson et al. 2002; Rinaudo 2015). In parallel, longitudinal panel methods using repeated observations and incorporating temporal and subject specific variability into coefficient estimates (Worthington and Hoffman 2008; Kenney et al. 2008; Harlan et al. 2009; Polebitski and Palmer 2010; Mieno and Braden 2011) have emerged as the preferred approach due to their ability to directly model micro-level causal processes (House-Peters and Chang 2011). The challenge for modelling consumption under drought conditions is therefore to develop micro-level models that provide a representation of both inter and intra household effects and also capture the underlying causal relationships that determine the evolution of water demand under changing sociotechnical conditions (Galán et al. 2009; Rinaudo 2015).

However, despite its substantial advantages micro-level modelling of water using habits (behaviours) in support of demand-side management has yet to be incorporated in drought response policies (Parker and Wilby 2013). The literature review presented above suggests doing so requires an integrative framework that can position demand as arising from the interaction of water use practices with systems of water provision (Medd 2007; Browne et al. 2014; Rinaudo 2015). Furthermore, while water use takes place in the home, it connects to different spatial and temporal scales, actors and activities and domestic consumption practices (Hoolohan and Browne 2016). We therefore need to link analysis of water using practices to the range of factors driving 'normal consumption' as well as to potential responses to drought conditions or interventions.

Drawing on the 'Energy Cultures' model (Stephenson et al. 2010) and building on Allon and Sofoulis (2006), Fig. 1 illustrates a 'Water Cultures' framework which can combine aspects of social norms (such as aspects of comfort, cleanliness, garden 'greenness'), practices (when and how to use water) and material cultures (water saving devices, metering, income, access to alternative sources- such as showering at work/gym). This approach forces the analyst to recognise that these factors interact in a range of ways to produce different 'everyday water demand' patterns and thus different responses to price manipulation, media messaging, changes in technologies, evolving social norms and practices or drought management interventions. It is crucial to understand that these factors are not static but continually evolving (Shove et al. 2012), that the interaction between them produces the dynamics of 'water demand' and that the units to whom this model applies (people) also interact adding additional inter-household dynamics.

This framework leads towards an integrated micro-level modelling approach which can capture both the uncertainty and heterogeneity of individual and/or household level variation and also highlights the need to explicitly model interactions between these 


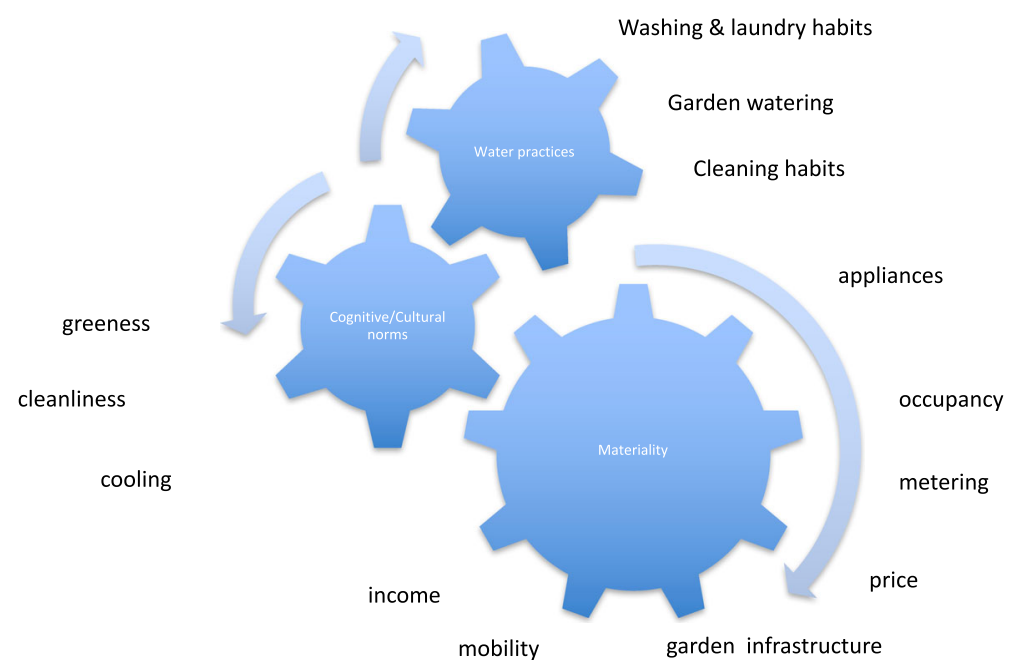

Fig. 1 Water cultures framework

entities to adequately represent the spread of new or evolving norms and social practices in response to a range of change inducing processes (Shove et al. 2012).

As we have shown in this paper, some of the evidence required to quantify the materiality-focused elements of the framework already exists. However, there are also major gaps in our knowledge regarding the nature and evolution of water demanding practices and we know very little about how cognitive and cultural norms play a quantitative role in affecting demand. In addition, as the paper has demonstrated, very little indeed is known about many of these elements in a drought response context.

\section{Conclusion and Future Directions}

This paper has synthesised the available literature on the factors associated with everyday domestic water consumption in temperate climates and under drought conditions as a basis for the future development of models that can allow the exploration of a range of drought response intervention scenarios.

Householders' response to drought has not been thoroughly studied and so this has not generally been considered in operational decisions about the most likely cost-effective drought management measures. Additionally, while much research has been devoted to the relationship between conservation attitudes and water use, a significant gap between attitudes and actual practices has been identified as has the need for more robust evidence on the differential response of household types to domestic water efficiency and drought response measures. In addition, whilst a number of well-designed trials have been conducted, generally small control sample sizes and the inability to take external factors into account add uncertainty to the results of many existing studies (Waterwise 2010).

Drawing on our evidence review, the 'Water Cultures' framework provides a means to conceptually and practically integrate these differing forms of evidence and approaches and to identify key research gaps. The framework can then provide the foundation for an 
integrated model not only of everyday water demand but specifically under drought conditions. Further, by overlaying this framework on the modelling requirement to preserve inter-household heterogeneity and model unit level processes suggests that implementing this framework at the micro-level will be key.

Future work should therefore look to develop two key activities. The first is to implement properly scoped large scale randomised control trials of water efficiency and drought response interventions on population representative samples to provide a robust evidence base. The second is to develop 'Water Cultures' based domestic end use water consumption models which can be used to explore the relative value of a range of drought interventions in similar temperate climates such as the UK.

Acknowledgements This work was supported by the UK Natural Environment Research Council funded "IMPETUS: Improving Predictions of Drought for User Decision-Making" project under the RCUK Drought Programme via grant NE/L010216/1.

Open Access This article is distributed under the terms of the Creative Commons Attribution 4.0 International License (http://creativecommons.org/licenses/by/4.0/), which permits unrestricted use, distribution, and reproduction in any medium, provided you give appropriate credit to the original author(s) and the source, provide a link to the Creative Commons license, and indicate if changes were made.

\section{References}

Agthe DE, Bruce Billings R, Dobra JL, Raffiee K (1986) A simultaneous equation demand model for block rates. Water Resour Res 22(1):1-4. https://doi.org/10.1029/WR022i001p00001

Ahmad S, Mirza M, Ali S, Lotia H (2016) Analysing household water demand in urban areas: empirical evidence from faisalabad, the industrial city of Pakistan. International Growth Centre, London

Alliance for Water Efficiency (2010) Public and consumer education programs. http://www.allianceforwaterefficiency. org/public education.aspx

Allon F, Sofoulis Z (2006) Everyday water: cultures in transition. Aust Geogr 37(1):45-55

Arbués F, Barberán R, Villanúa I, (2004) Price impact on urban residential water demand: a dynamic panel data approach. Water Resour Res 40: W11402. https://doi.org/10.1029/2004WR003092

Arbues F, Villanua I, Barberan R (2010) Household size and residential water demand: an empirical approach. Aust J Agric Resour Econ 54:61-80

Ashton V, Lawson, R., D. Marshallsay, and Ponsonby, K. 2015. Water efficiency evidence base statistical analysis. Final Report. Artesia Consulting Ltd, Bristol.

Atkins E (2015) UK demand forecasting: a cross-sector review. https://www.academia.edu/21028008/UK_ Demand_Forecasting_A_Cross-Sector_Review

Barr S (2006) Environmental action in the home: investigating the 'value-action' gap. Geography 91(1):43-54

Beal C, Stewart R (2011) South East Queensland residential end use study: final report. Urban Water Security Research Alliance, Queensland

Beal C, Stewart RA, Huang A (2010) South East Queensland residential end use study: baseline results - winter 2010. http://www98.griffith.edu.au/dspace/handle/10072/38126

Bello-Dambatta A, Kapelan Z, Butler D, Oertlé E, Wintgens T, Rozos E, Makropoulos C, Mamassis N (2014) Guidance on evaluation and selection of sustainable water demand management technologies, February. https://riunet.upv.es/handle/10251/35348

Bernardo V, Fageda X, Termes M (2015) Do droughts have long-term effects on water consumption? Evidence from the urban area of Barcelona. Appl Econ 47(48):5131-5146. https://doi.org/10.1080/00036846.2015.1042147

Bournemouth Water (2014) Final water resources management plan-2014 http://www.bournemouthwater.co. uk/Uploads/Docs/economic\%20regulation-ompetition/Water\%20resources\%20plan/New\%20documents\%20 September\%202014/Final_Water_Resources_Management_Plan_2014_Technical_Report.pdf

Browne AL, Medd W, Anderson B (2013) Developing novel approaches to tracking domestic water demand under uncertainty - a reflection on the "up scaling" of social science approaches in the United Kingdom. Water Resour Manag 27(4):1013-1035

Browne AL, Medd W, Anderson B, Pullinger M (2014) Method as intervention: intervening in practise through quantitative and mixed methodologies. In: Strengers Y, Maller C (eds) Intervening in social practices for sustainability: beyond behaviour change. Routledge, London 
Burton M, Marsh S, Patterson J (2007) Community attitudes towards water management in the Moore catchment, Western Australia. Agric Syst 92(1-3):157-178. https://doi.org/10.1016/j.agsy.2006.03.004

Campbell HE, Johnson RM, Larson EH (2004) Prices, devices, people, or rules: the relative effectiveness of policy instruments in water conservation. Rev Pol Res 21(5):637-662. https://doi.org/10.1111/j.15411338.2004.00099.x

Carragher BJ, Stewart RA, Beal CD (2012) Quantifying the influence of residential water appliance efficiency on average day diurnal demand patterns at an end use level: a precursor to optimised water service infrastructure planning. Resour Conserv Recycl 62:81-90. https://doi.org/10.1016/j.resconrec.2012.02.008

Chappells H, Medd W, Shove E (2011) Disruption and change: drought and the inconspicuous dynamics of garden lives. Soc Cult Geogr 12(7):701-715

Chicoine DL, Deller SC, Ramamurthy G (1986) Water demand estimation under block rate pricing. A simultaneous equation approach. Water Resour Res 22(6): 859-863. https://doi.org/10.1029/WR022i006p00859

CIWEM (2016) Water efficiency- helping customers to use less water in their homes. London. http://www. ciwem.org/wp-content/uploads/2016/02/Water-Efficiency.compressed.pdf

Clarke A, Grant N, Thornton J (2009) Quantifying the energy and carbon effects of water saving. Full technical report. http://www.elementalsolutions.co.uk/wp-content/uploads/2012/08/i-2504_EST_Water_report_pdf. Elemental Solutions. Hereford. UK

Critchley R, Lawson R, Marshallsay D (2015) WRMP19 methods - household consumption forecasting guidance manual. UKWIR, London. https://corporate.thameswater.co.uk/about-us/our-strategies-andplans/water-resources/document-library/-/media/829bffd962004ed7a24871f5ee00358a $\cdot a \mathrm{sh} \times$ ?bc= white $\& d b=$ web $\& 1 \mathrm{a}=\mathrm{en} \& \mathrm{thn}=1 \& \mathrm{ts}=\mathrm{c} 8281633-558 \mathrm{~b}-46 \mathrm{e} 2-\mathrm{ad} 3 \mathrm{f}-826 \mathrm{e} 27545 \mathrm{f} 25$.pdf

Dalhuisen JM, Florax RJGM, de Groot HLF, Nijkamp P (2003) Price and income elasticities of residential water demand: a meta-analysis. Land Econ 79(2):292-308. https://doi.org/10.2307/3146872

De Oreo W, Mayer P, Dziegielewski B, Kiefer J (2016) Residential end uses of water, version 2. Water Research Foundation, Denver. http://www.waterrf.org/Pages/Projects.aspx?PID=4309.

DEFRA (2008) Future water the government's water strategy for England https://www.gov. uk/government/uploads/system/uploads/attachment_data/file/69346/pb13562-future-water-080204.pdf

Dessai S, Sims C (2010) Public perception of drought and climate change in southeast england. Environ Hazard 9(4):340-357

Dolnicar S, Hurlimann A (2010) Australians' water conservation behaviours and attitudes. Aust J Water Res 14(1):43-53

Domene E, Saurí D (2006) Urbanisation and water consumption: influencing factors in the metropolitan region of barcelona. Urban Stud 43(9):1605-1623. https://doi.org/10.1080/00420980600749969

Downing TE, Butterfield RE, Edmonds B, Knox JW, Moss S, Piper BS, Weatherhead EK (2003) CCDEW: climate change and demand for water https://dspace.lib.cranfield.ac.uk/handle/1826/3576

Edwards K, Martin L (1995) A methodology for surveying domestic water consumption. Water Environ J 9:477488. https://doi.org/10.1111/j.1747-6593.1995.tb01486.x

Energy Saving Trust (2013) At home with water. http://www.energysavingtrust.org. uk/sites/default/files/reports/AtHomewithWater\%287\%29.pdf.

Energy Saving Trust (2015) At home with water 2. http://www.energysavingtrust.org. uk/sites/default/files/reports/AHHW2\%20final.pdf

Espey M, Espey J, Shaw WD (1997) Price elasticity of residential demand for water: a meta-analysis. Water Resour Res 33(6):1369-1374. https://doi.org/10.1029/97WR00571

Ferrara, I. 2008. Household behaviour and the environment reviewing the evidence. Organization for Economic Cooperation and Development (OECD), Paris. https://www.oecd.org/environment/consumptioninnovation/42183878.pdf

Fyfe J, May D and Turner A (2010) Techniques for estimating water saved through demand management and restrictions, in Integrated resource planning for urban water-resource papers, Waterlines report, National Water Commission, Canberra, Australia

Fyfe J, Mohr S, May D \& Rickwood P (2011) Statistical Evaluation of Water, Electricity and Greenhouse Gas Savings. From the Think Water, Act Water Residential Efficiency Programs report prepared for the ACT Environment and Sustainable Development Directorate by the Institute for Sustainable Futures, UTS, Sydney

Galán JM, López-Paredes A, del Olmo R (2009) An agent-based model for domestic water management in valladolid metropolitan area. Water Resour Res 45(5):W05401. https://doi.org/10.1029/2007WR006536

Gato S (2006) Forecasting urban residential water demand https://researchbank.rmit.edu.au/view/rmit:6244

Gato S, Jayasuriya N, Roberts P (2007) Temperature and rainfall thresholds for base use urban water demand modelling. J Hydrol 337 (3-4): 364-76. https://doi.org/10.1016/j.jhydrol.2007.02.014.

Gaudin S (2006) Effect of price information on residential water demand. Appl Econ 38(4):383-393. https://doi. org/10.1080/00036840500397499 
Goodchild CW (2003) Modelling the impact of climate change on domestic water demand. Water Environ J 17(1):8-12. https://doi.org/10.1111/j.1747-6593.2003.tb00423.x

Grafton RQ, Ward MB, To H, Kompas T (2011) Determinants of residential water consumption: evidence and analysis from a 10-country household survey. Water Resour Res 47(8):W08537. https://doi.org/10.1029 /2010WR009685

Guhathakurta S, Gober P (2007) The impact of the phoenix urban heat island on residential water use. J Am Plan Assoc 73(3):317-329. https://doi.org/10.1080/01944360708977980

Hajispyrou S, Koundouri P, Pashardes P (2002) Household demand and welfare: implications of water pricing in Cyprus. Environ Dev Econ Camb 7(4):659-685

Harlan SL, Yabiku ST, Larsen L, Brazel AJ (2009) Household water consumption in an Arid City: affluence, affordance, and attitudes. Soc Nat Resour 22:691-709. https://doi.org/10.1080/08941920802064679

Herrington PR (1998) Analysing and forecasting peak demands on the public water supply. Water Environ J 12(2):139-143. https://doi.org/10.1111/j.1747-6593.1998.tb00163.x

Hoolohan C, Browne AL (2016) Reframing water efficiency: determining collective approaches to change water use in the home. http://www.sciencedomain.org/Abstract/15914, July. http://imsear.hellis. org/handle/123456789/177913

House-Peters LA, Chang H (2011) Urban water demand modeling: review of concepts, methods, and organizing principles. Water Resour Res 47(5):W05401. https://doi.org/10.1029/2010WR009624

House-Peters L, Pratt B, Chang H (2010) Effects of urban spatial structure, sociodemographics, and climate on residential water consumption in Hillsboro, Oregon. JAWRA J Am Water Resour Assoc 46(3):461-472. https://doi.org/10.1111/j.1752-1688.2009.00415.x

Hurd BH (2006) Water conservation and residential landscapes: household preferences, household choices. J Agric Resour Econ 31(2):173-192

Inman D, Jeffrey P (2006) A review of residential water conservation tool performance and influences on implementation effectiveness. Urban Water J 3(3):127-143. https://doi.org/10.1080/15730620600961288

Jenkins G, Murphy J, Lowe J, Sexton D, Kilsby C, Jones P (2010) UK climate projections: briefing report. Version 2, December 2010. http://ukclimateprojections.metoffice.gov.uk/media.jsp?mediaid=87867 \&filetype $=$ pdf

Jensen JO (2008) Measuring consumption in households: interpretations and strategies. Ecol Econ 68(1-2):353361. https://doi.org/10.1016/j.ecolecon.2008.03.016

Jorgensen B, Graymore M, O’Toole K (2009) Household water use behavior: an integrated model. J Environ Manag 91(1):227-236. https://doi.org/10.1016/j.jenvman.2009.08.009

Kanakoudis, V. K. 2002. Urban water use conservation measures. J Water Supply: Res Technol - Aqua 51(3):153-63

Kemmelmeier M, Król G, Kim YH (2002) Values, economics, and proenvironmental attitudes in 22 societies. Cross-Cult Res 36(3):256-285. https://doi.org/10.1177/10697102036003004

Kenney DS, Goemans C, Klein R, Lowrey J, Reidy K (2008) Residential water demand management: lessons from Aurora, Colorado. JAWRA J Am Water Resour Assoc 44(1):192-207. https://doi.org/10.1111/j.17521688.2007.00147.x

Kowalski M, Marshallsay D (2005) Using measured microcomponent data to model the impact of water conservation strategies on the diurnal consumption profile. Water Sci Technol Water Supply 5(3-4):145-150

Lam S-P (2006) Predicting intention to save water: theory of planned behavior, response efficacy, vulnerability, and perceived efficiency of alternative solutions. J Appl Soc Psychol 36(11):2803-2824. https://oi. org/10.1111/j.0021-9029.2006.00129.x

Lawson R (2015) Statistical analysis of water efficiency, metering, rainwater and greywater savings. Watefcon 2015. University of Exeter, UK

Lee M, Tansel B \& Balbin M (2011) Influence of residential water use efficiency measures on household water demand: A four year longitudinal study. Resour Conserv Recycl 56:1-6

Linkola L, Andrews CJ, Schuetze T (2013) An agent based model of household water use. Water 5(3):10821100. https://doi.org/10.3390/w5031082

Lyman RA (1992) Peak and off-peak residential water demand. Water Resour Res 28(9):2159-2167. https://oi. org/10.1029/92WR01082

Maidment DR, Miaou S-P (1986) Daily water use in nine cities. Water Resour Res 22(6):845-851. https://doi. org/10.1029/WR022i006p00845

Makki AA, Stewart RA, Beal CD, Panuwatwanich K (2014) Novel bottom-up urban water demand forecasting model: revealing the determinants, drivers and predictors of residential indoor end-use consumption. Resour Conserv Recycl 95:15-37. https://doi.org/10.1016/j.resconrec.2014.11.009

Manouseli D, Kayaga SM, Kalawsky R (2017) Evaluation of water efficiency programs in single-family households in the UK: a case study. Water Science and Technology: Water Supply. https://doi.org/10.2166 /ws.2017.071 
Martinez-Espiñeira R (2002) Residential water demand in the Northwest of Spain. Environ Resour Econ 21(2): 161-187. https://doi.org/10.1023/A:1014547616408.

Mayer PW, De Oreo WB (1999) Residential end uses of water. AWWA Research Foundation and American Water Works Association, Denver, USA

Mayer P, De Oreo W, Towler E, Martin L, Lewis D (2004) Tampa water department residential water conservation study: the impacts of high efficiency plumbing fixture retrofits in single-family homes. Seattle public utilities and the USEPA, Boulder. https://www.tampagov.net/sites/default/files/water/files/Efficiency/Tampa-RetrofitFinal-Report.pdf

Medd W (2007) Drought and Demand in 2006: consumers, water companies and regulators: Full Research Report ESRC End of Award Report, RES-177-25-0001. ESRC: Swindon

Medd WP, Shove E (2007) The sociology of water use. UK Water Industry Research, London

Memon FA, Butler D (2006) Water consumption trends and demand forecasting techniques. In: Butler D, Memon FA (eds) Water demand management. IWA Publishing: London, pp 1-26

Met Office (2017) Eastern England: climate. Met office. http://www.metoffice.gov.uk/climate/uk/regionalclimates/ee

Mieno T, Braden JB (2011) Residential demand for water in the Chicago Metropolitan area. JAWRA J Am Water Resour Assoc 47(4):713-723. https://doi.org/10.1111/j.1752-1688.2011.00536.x

Millock K, Nauges C (2010) Household adoption of water-efficient equipment: the role of socio-economic factors, environmental attitudes and policy. Environ Resour Econ 46(4):539-565. https://doi.org/10.1007 /s10640-010-9360-y

Mukheibir P, Boyle T, Mitchell C (2013) End-use forecasting in the context of building adaptive water services. Water Util J 6(1):29-39

Musolesi A, Nosvelli M (2007) Dynamics of residential water consumption in a panel of Italian municipalities. Appl Econ Lett 14(6):441-444. https://doi.org/10.1080/13504850500425642

Mylopoulos YA, Mentes AK, Theodossiou I (2004) Modeling residential water demand using household data: a cubic approach. Water Int 29(1):105-113. https://doi.org/10.1080/02508060408691753

Olmstead SM (2013) Climate change adaptation and water resource management: a review of the literature. Energy Econ 46:500-509. https://doi.org/10.1016/j.eneco.2013.09.005

Ornaghi C, Tonin M (2015) The effect of metering on water consumption-Policy Note. University of Southampton, February 2015: Southampton

Parker JM (2014) Assessing the sensitivity of historic micro-component household water-use to climatic drivers. A Doctoral Thesis. Submitted in partial fulfilment of the requirements for the award of Doctor of Philosophy of Loughborough University, Loughborough: Loughborough. https://space. lboro.ac.uk/2134/14939

Parker JM, Wilby RL (2013) Quantifying household water demand: a review of theory and practice in the UK. Water Resour Manag 27(4):981-1011. https://doi.org/10.1007/s11269-012-0190-2

Polebitski A, Palmer R (2010) Seasonal residential water demand forecasting for census tracts. J Water Resour Plan Manag 137(27):27-36

Prudhomme C, Shaffrey L, Woollings T, Jackson C, Fowler H, Anderson B (2015) IMPETUS: improving predictions of drought for user decision-making. In: Andreu J, Solera A, Paredes-Arquiola J, HaroMonteagudo D, van Lanen H (eds) Drought: research and science-policy interfacing. Taylor \& Francis, London, p 273

Pullinger M, Browne A, Anderson B, Medd W (2013) Patterns of water: The water related practices of households in southern England, and their influence on water consumption and demand management. Lancaster University: Lancaster, UK. Available at: http://www.sprg.ac.uk/projects-fellowships/patternsofwater/patterns-of-water-final-report

Qi C, Chang N-B (2011) System dynamics modeling for municipal water demand estimation in an urban region under uncertain economic impacts. J Environ Manag 92(6):1628-1641. https://doi.org/10.1016/j. jenvman.2011.01.020

Renwick ME, Archibald SO (1998) Demand side management policies for residential water use: who bears the conservation burden? Land Econ 74(3):343-359. https://doi.org/10.2307/3147117

Renwick ME, Green RD (2000) Do residential water demand side management policies measure up? An analysis of eight california water agencies. J Environ Econ Manag 40(1):37-55. https://doi.org/10.1006 /jeem.1999.1102

Rinaudo J-D (2015) Long-term water demand forecasting. In: Grafton Q, Daniell KA, Nauges C, Rinaudo J-D, Chan NWW (eds) Understanding and managing urban water in transition (pp 239-68). Global issues in water policy 15. Springer, Netherlands. https://doi.org/10.1007/978-94-017-9801-3_11

Robinson D, Adeyeye O, Madgwick D, Church A (2014) Review of attitudes and preferences for water efficiency in homes. WATEF Network/ University of Brighton, Brighton 
Schleich J, Hillenbrand T (2009) Determinants of residential water demand in Germany. Ecol Econ 68(2009):1756-1769

Shove E (2003) Comfort, cleanliness and convenience: the social organisation of normality. Berg, London

Shove E, Pantzar M, Watson M (2012) The dynamics of social practice: everyday life and how it changes. SAGE, London

Sofoulis Z (2011) Skirting complexity: the retarding quest for the average water user. Continuum 25(6):795-810

Stephenson J, Barton B, Carrington G, Gnoth D, Lawson R, Thorsnes P (2010) Energy cultures: a framework for understanding energy behaviours. Energy Policy 38(10):6120-6129. https://doi.org/10.1016/j. enpol.2010.05.069 The socio-economic transition towards a hydrogen economy - findings from European research, with regular papers

Stewart RA, Willis RM, Panuwatwanich K, Sahin O (2013) Showering behavioural response to alarming visual display monitors: longitudinal mixed method study. Behav Inform Technol 32(7):695-711. https://oi. org/10.1080/0144929X.2011.577195

Tillman P (2012) Water Savings from Residential Toilet Replacement Program. Ozwater'12, 8-10 May 2012, Sydney

Tsai Y, Cohen S,Vogel RM (2011) The impacts of water conservation strategies on water use: four case studies. J Am Water Res Assoc 47:687-701

Turner A, White S, Beatty K, Gregory A (2005) Results of the largest residential demand management program in Australia. Santiago, Chile

Turner A, White S, Kazaglis A and Simard S (2007) Have we achieved the savings? The importance of evaluations when implementing demand management. Efficient 2007: Proceedings of 4th IWA Specialist Conference on Efficient Use and Management of urban Water Supply, Jeju, Korea.

Turner A, Willetts J, Fane S, Giurco D, Chong J, Kazaglis J, White S (2010) Guide to demand management and integrated resource planning (Update on Original 2008 Guide). Institute for Sustainable Futures. http://hdl. handle.net/10453/37622

Turner A, Boyle T, Mohr S, Fyfe J \& Bruck J (2012) Quantitative Evaluation of Residential and School Efficiency Programs, prepared by the Institute for Sustainable Futures for the Hunter Water Corporation.

UKWIR (2013) Understanding the impacts of drought restrictions. Report Ref. No. 14/WR/01/13. London

Wang Y-D, Song J-S, Byrne J, Yun S-J (1999) Evaluating the persistence of residential water conservation: a 1992-1997 panel study of a water utility program in Delaware. JAWRA J Am Water Resour Assoc 35(5): 1269-1276. https://doi.org/10.1111/j.1752-1688.1999.tb04213.x

Waterwise (2008) Evidence Base for Large-scale Water Efficiency in Homes. Prepared by Waterwise, London, UK. http://www.waterwise.org.uk/data/2008_Waterwise_evidence_base.pdf

Waterwise (2009) Reducing water wastage in the UK. Annual Report 2008-2009. London http://www.waterwise. org.uk/data/resources/10/2009_annual-report.pdf

Waterwise (2010) Evidence base for large-scale water efficiency in Homes. Phase II-Interim report. London. http://www.waterwise.org.uk/data/resources/14/evidence-base-for-large-scale-water-efficiency-in-homesphase-ii-interim-report.pdf

Williamson P, Mitchell G, McDonald AT (2002) Domestic water demand forecasting: a static microsimulation approach. Water Environ J 16(4):243-248

Willis RM (2010) Domestic water end use study: an investigation of the water savings attributed to demand management strategies and dual reticulated recycled water systems. Griffith University, Australia. https:/experts.griffith.edu.au/publication/n5e8e667504cb9ccc35b68b118de6629f.

Willis RM, Stewart RA, Panuwatwanich K, Williams PR, Hollingsworth AL (2011) Quantifying the influence of environmental and water conservation attitudes on household end use water consumption. J Environ Manag 92(8). Elsevier Ltd: 1996-2009. https://doi.org/10.1016/j.jenvman.2011.03.023

Willis RM, Stewart RA, Giurco DP, Talebpour MR \& Mousavinejad A (2013) End use water consumption in households: impact of socio-demographic factors and efficient devices. J Clean Prod 60:107-115. https://oi. org/10.1016/j.jclepro.2011.08.006

Worthington AC, Hoffman M (2008) An empirical survey of residential water demand modelling. J Econ Surv 22(5):842-871

Zhou SL, McMahon TA, Walton A, Lewis J (2000) Forecasting daily urban water demand: a case study of Melbourne. J Hydrol 236(3-4):153-164. https://doi.org/10.1016/S0022-1694(00)00287-0 